\title{
A Proposed Integrated Supply Chain Management Framework for Tuna Fishery in Palabuhanratu
}

\author{
ATIKAH NURHAYATI ${ }^{1}$, A.H.PURNOMO ${ }^{2}$ \\ ${ }^{1}$ Faculty of Fisheries and Marine Science, Padjadjaran University, INDONESIA \\ ${ }^{2}$ Research Center for Marine and Fisheries Product Processing and Biotechnology, INDONESIA
}

\begin{abstract}
Tuna production potential of Palabuhanratu, Sukabumi District, is very high but the fishery is not supported by a good supply chain. In this location, there are two existing chains namely fresh and derivativeproduct chains; both are influenced significantly by seasonal variables. This research aims to analyze integrated supply chain management for tuna fishery in Palabuhanratu. Data for this research comprises both primary and secondary data. Primary data were collected through interviews with 20 respondents representing fishermen, 10 representing wholesalers, 10 representing retailers, 10 representing consumers, all of which were drawn from following the snowball sampling technique. Meanwhile, secondary data were time series tuna production statistics made available from the printed report of the Sukabumi District Fishery Office. This research employed the factor analysis and fisheries supply chain management model as the main methodological tools. The result showed that among others, the most influential factors for tuna demand in the research location are price of fish, tuna product diversity, and distribution of tuna catch. On the other hand, in the supply side the most influential factors are fishing season and tuna species. It was identified from the research that with regard to the existing chains, this research identified that there are variants of both the fresh fish and derivative product chains, each of which have some particular drawbacks related to influential factors observed in the other part of this research. It is worth noting here that variants of the fresh tuna chain are: (i) fishers, auction place, wholesalers, retailers, consumers, (ii) fishers, auction place, consumers, (iii) fishers, consumers. Variants of the derivative-product chain are: (i) fishers, auction place, wholesalers, processors, processed fish wholesalers, processed fish retailers, consumers, (ii) fishers, auction place, processors, processed fish wholesalers, processed fish retailers, consumers, (iii) fishers, auction place, processors, processed fish retailers, consumers. In general, this research suggests that improvement should be made through the introduction of an integrative approach aiming to incorporate tools necessary to mitigate negative influential factors and to take advantage the positive ones.
\end{abstract}

Key words: consumer, integrated, marketing, supply chain, tuna fishery.

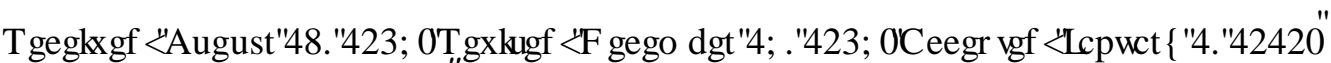

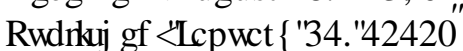

\section{Introduction}

One of the areas in West Java that has considerable fisheries potential is Sukabumi of the West Java Province. Fisheries are all activities related to fishery product management, starting from preproduction, production, processing to marketing, which is carried out in a fisheries business system. In Sukabumi the most potential fisheries are capture fisheries, owing to the abundant resources supported by adequate facilities. Among these facilities is the fishing port, which accommodate government service and business activities. The port is equipped with facilities for fishing boat docking and anchoring, fish loading and unloading, shipping safety and other relevant supporting activities (Agency of Marine and Fisheries, Sukabumi West Java Province, 2014).[1].

The Sukabumi fishingport, (officially called the Palabuhanratu National Fishing Port) directly links to the highly potential resource of the Indian Ocean waters. As observed, the facilities of the port has met the required standard as stated, namely functions of mooring and anchoring services of fishing vessels, loading and unloading, fostering quality and processing, marketing and distribution of fish, collecting catch and fishery data, environmental control (Hutapea 2017).[2]. This port is one of the ports the West Java that provides an important contribution to the fisheries sector in province and where tunas are the leading commodities. Based on the Decree of the Minister of Maritime Affairs and Fisheries of the Republic of Indonesia Numbered 107/Kepmen-Kp/2015 concerning the Tuna Fisheries Management Plan, exploitation and management of these species need special treatment, mainly due to the fact that the existence of tuna resources in a waters is strongly 
influenced by the oceanographic conditions of these waters, especially temperature and salinity.[3].

Tuna production from this area is supplied to both domestic consumers as well as international markets. The demand for tuna of fresh quality from fishermen is increasing every year. So far, the largest tuna international markets are Japan, the United States and the European Union. According to the Food and Agriculture Organization (2006) [4], tuna exports to Japan by $27 \%$, and to the United States by $17 \%$ volume and value of $12 \%$. The fact shows that the increasing tuna market opportunities need to be balanced with supply chain management, because these commodities have economic value, high demand, and high benefits for fishermen and the community.[5].

The need for proper supply chain management in tuna fisheries commodities in the Palabuhanratu can be linked primarily to the intersts of the government to maximize economic value, to maintain fish stock and product quality, and to improve accessibility of the community. An effective and efficient management of tuna facilities and transportation in the supply chain is expected to be able to improve performance, time and energy efficiency, to reduce operational costs, to maintain tuna quality, and to broaden marketing distribution.

Referring to the literature, the notion of supply chain mentioned above denotes a network of companies (industrial supply nodes), which work together to create and deliver a product's to the end users.[6]. Meanwhile, supply chain management is defined as a series of approaches applied to integrate suppliers, entrepreneurs, warehouses and other storage areas efficiently so that products can be produced and distributed to consumers with the right quantity, quality, location and time to minimize costs and satisfy consumer needs [7]. Within this network, products move from production to consumption, including preproduction and post-consumption activities. [8]. In the supply chain, production is focused on efficiency of logistic uses, upstream and downstream, which are mostly aimed at boosting products to the market. The supply chain is mostly related to costs and how long it will take to present products for sale.

Logistics system too has a strategic role in synchronizing and aligning progress between economic sectors and between regions in order to realize it inclusive economic growth, as well as being a strong hold for national economic sovereignty and resilience.
The supply chain has three main parts: supplying raw materials to the manufacturing unit; making raw materials into semi-finished or finished products; and distribution to ensure products reach consumers The tuna supply chain includes: (1) supplying production input raw materials such as ships, fishing gear, fuel, cold storage, (2) handling tuna catches to be consumed fresh fish and tuna products or derivative product of tuna (3) distribution of fresh tuna and processed tuna to ensure products reach consumers [9].

On the other hand, the value chain of how fresh tuna works bringing fresh tuna products to the market whose primary purpose is value chain management is to maximize net income [10].

The Sukabumi fresh tuna value chain is divided into two patterns, international and domestic markets. The chain normally involves a large number of intermediaries between fishermen, fish auction places, collectors, large traders, small traders and consumers [11]. Inefficiency is detected in the value chain of this fishery and therefore it needs improvement. Eventhough production and production potential is very high, in general the added value is low and margin disparity between value chain nodes is wide. Given this, this research aims to formulate integrated supply chain management for tuna fishery in Palabuhanratu, which is necessary to overcome the problems.

\section{Research Methods}

This research was carried out based on a survey methodological approach. Following from this approach, information was mainly primary data collected from a portion of the population to represent the entire population. In total, 20 respondents representing fisherman, 10 representing wholesalers, 10 representing retailers, and 10 representing consumers were drawn from the population using the snowball sampling technique. In depth terviews were conducted to these respondents.

\subsection{Time and Place of Research}

This research was conducted in Palabuhanratu, Sukabumi. The research location was focused on several fishing port transits, landing sites, and fish processing centers. This research was conducted in February - September 2019.

\subsection{Data Processing Method}

In addition to primary data as mentioned above, secondary data were also collected. Aspects that were asked in the interview were related to fish 
production, fish distribution, production costs, distribution costs, and institutional marketing channels.

In abnormal supply chain conditions, there are risks that can threaten the sustainability of the supply chain, both those that are easy to replace and those that are not easy to replace quickly within their management timeframe [12]. Recognizing this, a formula was used to calculate the consequences of the risk of a product in the supply chain as follows:

$$
\alpha=\frac{\delta \text { replace }}{\delta \text { collapse }}
$$

Informations:

$\alpha$

$\delta$ replace : The time it takes for a supply chain to replace a sub-product or time needed to handle interruption of a product flow, and returns to normal scheduling conditions with the same quality level.

$\delta$ collapse : The time of the subproduct failed to be completed before the supply chain

experience a loss at a critical point in service the market

Based on the $\alpha$ value, the following are the assessment indicators for integrated supply chain management for tuna fishery in Palabuhanratu

Table 1. Value of risk consequences for integrated supply chain management for tuna fishery

\begin{tabular}{|l|l|l|}
\hline Consequence & Information & $\alpha$ \\
\hline Important & Irreplaceable & 1.0 \\
\hline Necessary & $\begin{array}{l}\text { Not easy to } \\
\text { replace }\end{array}$ & 0.6 \\
\hline Weeded & $\begin{array}{l}\text { Easily } \\
\text { replaced }\end{array}$ & 0.3 \\
\hline & $\begin{array}{l}\text { Easily } \\
\text { replaced }\end{array}$ & 0.1 \\
\hline
\end{tabular}

\subsection{Validity and Realiability Test Data}

Validity test was used to determine the level of validity of the questionnaire instrument used in data collection. Using valid and reliable instruments in data collection it was expected that research results would be valid and reliable. Reliability testing in this reserach was conducted by calculating the value of Cronbach's Alpha instruments from each of the research variables tested [13].

\section{Problem Solution}

\subsection{Research Location}

Palabuhanratu National Fishing Port in Sukabumi District and located in the Indonesia's Fisheries Management Areas No 573. Geographically, the district is located at position 06 $\circ 57^{\prime}-07^{\circ} 25$ 'South Latitude and $106^{\circ} 49^{\prime}-107^{\circ} 00^{\prime}$ East, while Palabuhanratu is at $06^{\circ} 57^{\prime}-07^{\circ} 07$ 'South Latitude and $106^{\circ} 22^{\prime}-106^{\circ} 33$ 'East [1].

Palabuhanratu National Fishing Port is located in Palabuhanratu Bay which is part of the Indian Ocean waters (WPP-RI 573). Against the backdrop of the potential of fisheries around Palabuhanratu, the Port of Fisheries Archipelago was built in Palabuhan Ratu 1991-1993 with development funds at the initial stage sourced from the Asian Development Bank (ADB) and the Islamic Development Bank (ISDB) and on 18 February 1993 was inaugurated operation by the President of the Republic of Indonesia.[14].

Palabuhanratu National Fishing Port has undergone two stages of development, namely the first phase of construction in 1993 then the second phase of construction during the 2003 period. The first phase of the Port of Fisheries Development is intended to support the activities of fisheries, especially fishing units with vessels up to 30 GT size and the construction of the second stage of the Port of Fisheries to support the activities of vessels ranging from $30 \mathrm{GT}$ up to $150 \mathrm{GT}$ [1].

Palabuhanratu National Fishing Port is one of the Fishery Ports which is located not too far from the capital city of Jakarta. Pelabuhanratu also deals directly with Indian ocean waters that have great fisheries potential, especially Tuna fish species and their marine tourism areas.

Palabuhanratu costal area has a tropical climate with two main seasons namely the west and east monsoons. The west season or often known as the rainy season occurs in December to March. During the western season, many fishermen do not engage in fishing activities, due to the very large waves. Besides being referred to as the west season, this season is also often referred to as low season by the Palabuhanratu fishermen because the fish catch tends to be small when fishing. This happens because the tuna likes warm waters, so when the rainy season causes sea surface temperatures to be low, the tuna will migrate to warmer waters. 
The east or dry season lasts from June to September. This dry season is widely used by fishermen to carry out fishing operations to the sea because of relatively calm conditions, so that this season is often referred to as the high season of fishing because of the large catches.

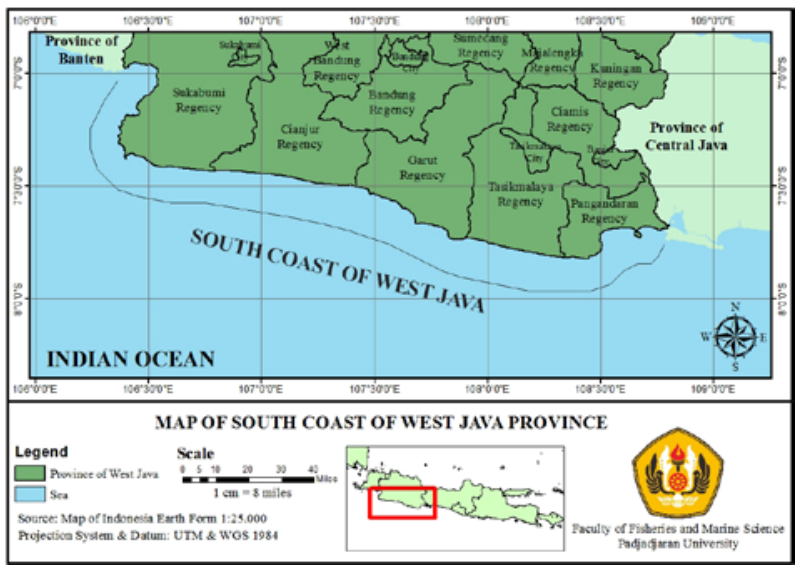

Fig 1. Research Locations

Figure 1 shows the research location in Palabuhanratu, which is in the south cost of West Java Province. Pelabuhanratu is the largest bay along the southern coast of Java. Pelabuhanratu and has the potential of capture fisheries resources. Utilization of capture fisheries resources cannot be separated from the role of fishermen as the main actors in the production of fishery products.

The most potential species of the fisheries resources in Palabuhanratu is tuna. Tuna has economic value but to realize the potential value it needs proper handling, starting from pre-production, production, processing and distribution is one chain to increase the added value of a fishery product.

\subsection{Validity and Realiability Data}

The validity test results for the questionnaire delivered to the interviewed 20 fishermen, 10 wholesellers, 10 retailers, 10 consumers confirmed that the data were valid. It was proven that the validity value was higher compared to the value of $r$ table, which was 0.707 in the 0.05 significance level.

The results of the reliability test calculations for raw material providers showed that the Cronbach Alpha Coefficient value was 0.95 , which means the value was at an interval of 0.8-1.0, meaning that the reliability was good. This value indicates that the questionnaire submitted for respondents could be trusted.

\subsection{Characteristict of Respondent and Their Fishing Practices}

This reserach used respondents 50 respondents. These respondents consisted of fishermen, collectors, large traders, small traders, fishery product processors, namely processed tuna and distributors

The respondents interviewed operate fishing activity in the fishing ground using a number of gears targeting tuna species. These gears are fishing gear is used to capture tuna are the purse-seine net, longline, pole-and-line and gillnet. Tuna with high quality is caught with a fishing gear whose used is accordance with the movement of tuna to be caught in good condition. This special tuna fishing gear is called tuna longline. Components of longline tuna are float, float line, main line, branch line, hooks and bait [15].

Catching of neritic tuna species done with a variety of sizes ranging from juvenile to adulthood with a variety of fishing gear such as longline, trawl and gill nets. Longline tuna generally operate on the high seas or reach ocean waters [16]. This fishing gear is passive, waiting for the bait to be eaten by the target fish. After the fishing line is lowered into the water, then the ship's engine is turned off so that the boat and fishing gear will drift in the direction of the current or often called drifting. Drifting lasts for approximately four hours. Furthermore, the fishing line raised back onto the ship. Longline feeds must be attractive. Utilize correctly and responsibly in accordance with the principles of sustainable fisheries management.

The productive age of people to work is between 15-64 years. States that the productive age of people to work is between 15-64 years. [17]. Based on this reserach $88 \%$ it this are in the productive age. Productive age has the ability to improve performance in accordance with their line of work.

Level educations of respondents is $50 \%$ elementary schools, $30 \%$ junior high schools, $20 \%$ senior high schools. Based on this reserach level of respondents education was influencing decision making in fisheries resource management activities, especially for tuna fishing.

\subsection{Types and Production of Tuna in Palabuhanratu}

Tuna that lives in the Indonesian marine waters are grouped into two types, namely large tuna and small tuna. Big tuna includes yellowfin tuna, albacore, big eye tuna, and southern bluefin tuna. Meanwhile, small tuna consists of skipjack tuna, eutynnus affinis, auxis thazard and thunnus tonggol. Based on this reserach in Palabuhan Ratu, have 
several species of commercial tuna's , can be seen in table 2.

Table 2. Major species of commercial tunas

\begin{tabular}{|l|l|}
\hline English name & Scientific name \\
\hline Skipjack tuna & Katsuwonus pelamis \\
\hline Yellowfin tuna & Thunnus albacares \\
\hline Bigeye tuna & Thunnus obesus \\
\hline Albacore tuna & Thunnus alalunga \\
\hline Bullet tuna & Auxis rochei \\
\hline Longtail tuna & Thunnus tonggol \\
\hline Frigsted tuna & Auxis thazard \\
\hline Eastern Little tuna & Eutynnus affinis \\
\hline
\end{tabular}

Tuna's body is elongated like a cigar and has a strong keel on the tail fin flanked by two small keel at the tip. Cross section of tuna's body is elliptical or slightly rounded. The color of the back is dark blue, sometimes almost black and the abdomen is whitish which sometimes changes when the fish is dead.

Tuna production in Palabuhanratu until now is still oriented to the international market with export destination countries Japan, USA, European Union. But lately the volume of tuna exports in Palabuhanratu has decreased. The decline in tuna exports was caused by a decline in domestic tuna supply, based on research results tuna production in Palabuhanratu has decreased, we can seen in Fig 5 9 tuna's production in Palabuha Ratu.

Spread Skipjack can be divided into two parts, horizontal spread or spread according to the geographical location of the waters and vertical spread or spread according to the depth of the waters [18]. Geographical distribution and abundance of fish skipjack tuna is affected by availability food as desired in the right amount and time. Even fish Skipjack migrated to looking for new areas that are rich in wealth food source.

Skipjack tuna production in Palabuhanratu very fluctuating and tends to decrease the amount of production until the year 2018. Based on this research the highest production in 2005 amounted to $1,860,679 \mathrm{~kg}$ and there was a sharp decline in production in the years 2016 be 134,792 kg [1]. Based on this research the problems faced are related to optimization tuna catch is the limited area fishing potential and abundance of fish.

Based on this reserach that the large amount of fish catch production. Skipjack are not only influenced by the number of fishing gear but there are other factors such as the use of fishing fleets, the seasonal nature of fishing and the number of actors fishing and illegal, unreported and unregulated fishing (IUU Fishing).
Longtail tuna one species of tuna that lives in tropical Indo-Pacific waters. This fish is epipelagic, and especially neritic, but avoids turbid waters and low salinity near estuary [21]

Longtail tuna production in Palabuhanratu decreased production. Longtail tuna production the highest production in 2006 amounted to $506,543 \mathrm{~kg}$ and there was a sharp decline in production in the years 2006 be 2015 be nol production and in the year 2018 longtail tuna production is 13,919 kg [1]. Longtail tuna production in Palabuhanratu a downward trend, in longtail tuna production Palabuhanratu at the same time with the trend decreased production of other neritic tuna such as eastren little tuna. Both types of fish these come from the same fishing gear, which is trawl and gillnets [23].

Decreased tuna production in Indonesia possible because of fishing by fishermen traditional with various forms of fishing gear and is a bycatch on large-scale / industrial fishing.

Eastern little tuna production in Palabuhanratu very fluctuating and tends to decrease.Based on this research the highest production in 2003 amounted to $182,463 \mathrm{~kg}$ and there was a sharp decline in production in the years 2007 be 9,607 $\mathrm{kg}[1]$. Resource management eastern little tuna must pay attention to the biological aspects because these resources have the ability to increase or decrease.[22].

Based on this reserach one of the fishing gear commonly used to catch eastern little tuna in Palabuhanratu is danish seine. The catch at any time depending on the number of fish populations beginning of the period and the amount of fishing effort used. If these resources are exploited through fishing activities, the size of abundance will be change. The change is the difference between the growth rate of biomass and the amount of biomass captured.

Based on this research one of the causes of the decline in production of eastren little tuna is that the fleet and fishing equipment have experienced a decline and climate change is unpredictable. The amount of tuna production is influenced by fishing efforts, fishing methods, fisherman skills, abundance of fish stocks and environmental carrying capacity.

Bullet tuna is a sea fish that belongs to a type of small pelagic fish. Pelagic fish are fish that live on the surface layer of water to the middle (mid layer). Neritic tuna are a group of tuna whose habitat is in the waters of neritic or shallow waters with a depth of less than 200 meters, one of which bullet tuna. 
Bullet tuna is a small tuna., are a fish resource epipelagic, neritic and oceanic in warm waters like in the territory of Palabuhanratu [24].

Bullet tuna production in Palabuhanratu very fluctuating. Based on this research the highest production in 2012 amounted 1,143,323 kg and in 2018 amounted 1,136,682 $\mathrm{kg}$ and there was a sharp decline in production in the years 2010 be 6,318 $\mathrm{kg}[1]$. Arrest activity increased again in transitional season between west and east monsoon which is also followed by increased catch bullet tuna.

Frigsted tuna included in the neritic with habitat in sea level to a depth of 50 meters $[25,26]$. Catching frigsted fluctuating every year with various types of fishing gear i.e gill net, trawl and huhate. Frigsted tuna production in Palabuhanratu very fluctuating. Based on this research the highest production in 2003 amounted 20,042 kg [1].

Based on this research frigsted tuna is a consumption fish for the community. As a result of high consumer demand in the fish market, causing fishermen to catch on a large scale. This large-scale fishing activity can disrupt the production of frigsted tuna and reduce it's population. Initially the fishing gear used was trawl, then fishermen were prohibited from using trawl and then replaced with purse seine, this condition causes a decrease in frigsted tuna production.

The concept underlying management efforts is that resource utilization must be based on the system and its natural carrying capacity. The size of the catch depends on the amount of natural stock available in the waters and the natural ability of the habitat to produce fish biomass. management efforts begin with a stock assessment, so that the potential of the natural stock can be known. At the same time, monitoring of arrests was also carried out, especially for monitor whether overexploitation has occurred, by looking at the catch per effort (CPUE) and size that is caught [27].

\subsection{Integrated supply chain management for tuna fishery in Palabuhanratu.}

Based on this reserach tuna is a potential product for continuing developed and become one of the leading commodities in Palabuhanratu Sukabumi. Tuna is sold in the form of frozen, fresh, or ambient. This frozen tuna has a much smaller market share compared to the other two types of products. Fresh tuna is a product that is classified as superior compared to frozen tuna products. Ambient tuna referred to in this sense is tuna packaged in cans or pocket so that it can stored at room temperature without having to be at the temperature of the refrigerator.
Tuna, as a fishery product, actually has superior value about its nutritional content which is good for the body. However, tuna is faced with environmental issues that make prospective buyers consider it. Among these is the existence of ecolabels such as Marine Stewardship Council (MSC). Each product uses the MSC label means the product comes from sustainable fisheries well managed.

The marketing of tuna fish in Palabuhanratu experiences many relatively low price differences between the amount paid by consumers and the amount of price determined by fishermen which naturally influences the marketing margin.

Aquaticpreneurship marketing is the thing very important completion of the production process fishery. Marketing conditions give rise a market cycle or circle commodity. When marketing is not smooth and not giving an improper price for fishermen then this condition will be affect the motivation of fishermen, if bad marketing caused by the smallest central production area, no there is a marketing chain market too long, or there is one buyer and another so. Conditions like this are certain detrimental to the manufacturer[28].

Based on this reserach related and supporting industries are industries that are directly involved in tuna aquaticpreneurship systems ranging from upstream to downstream. Good related and supporting industries will support the competitiveness of processed tuna commodities. Industries related to national tuna commodity competitiveness consist of upstream industries, namely fishing and downstream industries, namely post-fishing and processing industries. The tuna rocessing industry, especially in Palabuhanratu is based on the price of tuna at the fish auction level.

Fish auction price tuna in Palabuhanratu which has the highest price, i.e.skipjack in 2018 that Rp17,360/kg and in 2019 that Rp. 20,000/kg. Longtail tuna averange price in 2018 is Rp 17,000/kg. Eastren little tuna averange price in 2018 is Rp. $18,000 / \mathrm{kg}$. Bullet tuna averange price in 2018 is Rp. 14,000/kg and frigate tuna averange price in 2018 is Rp 18,000/kg.[1].

Based on this reserach fish sold to the fish auction place would usually be purchased by a basket or intermediary trader. Baskets or intermediary traders are the ones who provide capital to fishermen during their fishing business at sea or who provide loans for operational costs at sea. So even though there is an auction, traders or intermediaries still have a high bargaining position in determining the price because usually the auction falls at the price determined by the trader or intermediary trader as the giver of capital and rarely 
is the price of fish determined by the auctioneer through the actual auction.

Based on this reserach institutional and marketing channels tuna fish in Palabuhanratu is community which organizes marketing, distribute products and services from producers to the end customer, as well as having relationships with other individuals.

The size of the marketing costs of the results of the arrest depends on the size of the marketing institutional activities and the number of facilities needed in the process of production movement.

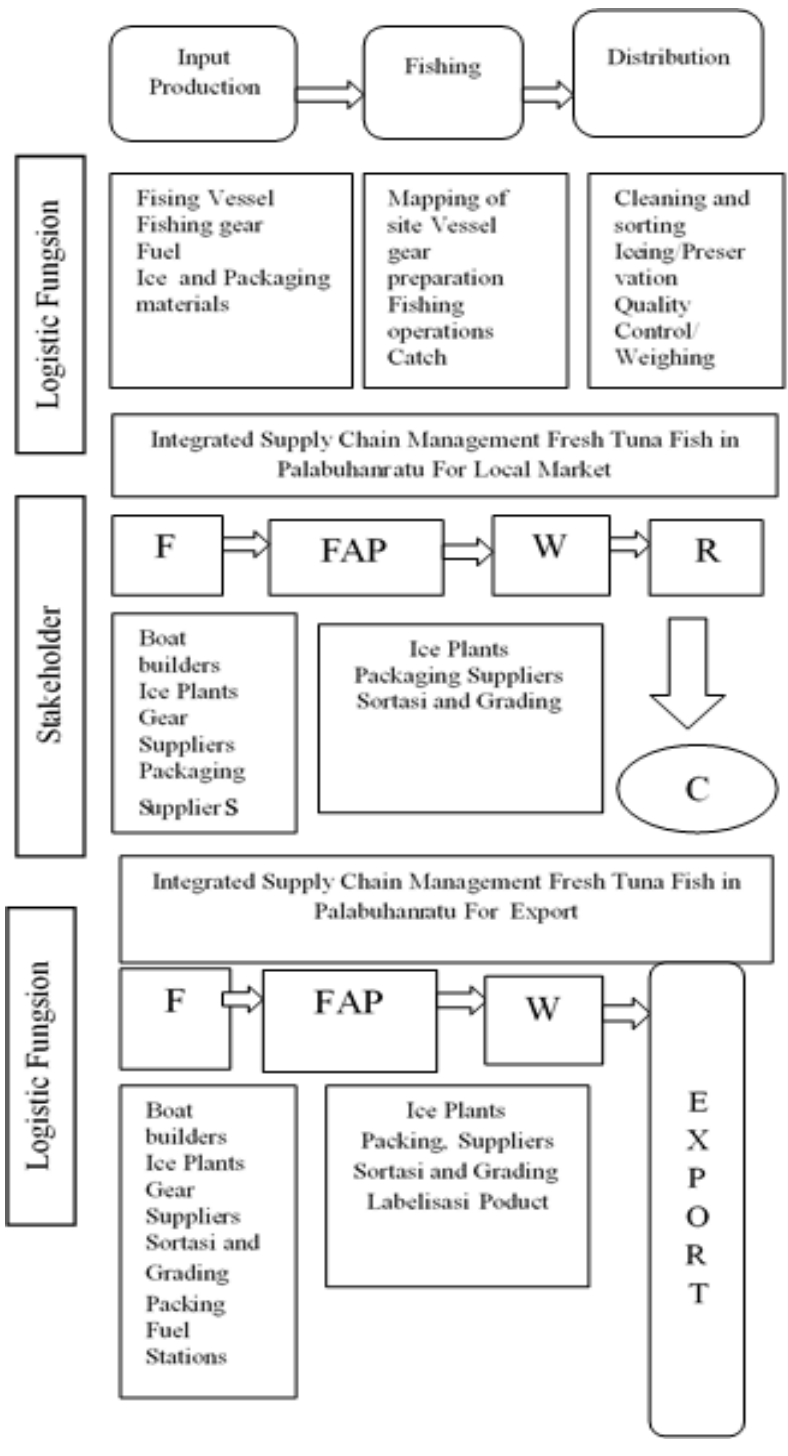

F : Fisherman

FAP : Fish Auction Place

W : Wholesaler

Fig 2. Framework Integrted Supply Chain Management Fresh Tuna In Palabuhanratu

Capture fisheries business, especially tuna is growing rapidly along with the increasing market demand due to the increase in the level of public consumption. Domestic and international market conditions are still very open so there are still business opportunities to be increased by taking into account the aspects of sustainable capture fisheries production.

Tuna distribution in Palabuhanratu domestic market destinations to Surabaya and Jakarta. Export destinations have decreased, this is because the tuna production trend in Palabuhanratu has decreased. Based on this research the success of exporters to become suppliers of supermarkets will certainly bring a positive impression on tuna products in Palabuhanratu, because the large retailers are trusted by the community as a provider of quality food ingredients and prioritizing environmentally friendly elements. Tuna exports in Palabuhanratu,i.e Thailand $53 \%$, Spain $18 \%$, Italy $15 \%$ and Portugal $14 \%$, but tuna exports in Palabuhanratu have decreased in line with declining catches.

Based on this research the tuna marketing channel in Palabuhanratu : (1) fisherman, fish auction place, wholesaler,retailer and consumer : (2) fisherman, fish auction place and consumer ;(3) fisherman and consumen.

Fish logistics system is a fish supply chain management system and fishery products, materials and production equipment, as well as information ranging from procurement, storage, up to distribution, as a unity of policies to increase capacity and stabilize the upstream-downstream fisheries production system, control price disparities and to meet domestic consumption needs [29].

In figure 2 framework integrted supply chain management fresh tuna in Palabuhanratu including logstict fungsion and stakeholder. Tuna fishery products has a easily damaged and high price fluctuations make the seller's bargaining position will be weaknes.

To maintain the quality of tuna and even meat increase the market share of fresh tuna, implementation good processing since the catch tuna needs to be subscribed on the ship to follow the pattern of application integrated quality in this case the system Hazard Analysis Critical Control Point (HACCP) supported by the use of field experts in terms of quality that will help company in giving advice for achieving good quality.

Integrted supply chain management proccesing tuna fish in Palabuhanratu. Based on this research opportunities the tuna fishing market in Palabuhanratu the export market (downstream side) certainly not regardless of the availability of commodity raw materials tuna in the waters of the south coast of Java (upstream side), in terms of 
quantity and quality of ingredients tuna raw materials can be processed into several derivative products of tuna such as shredded tuna, tuna meatballs, canned tuna so that it can make a positive contribution to the tuna commodity market share especially in Palabuhanratu.
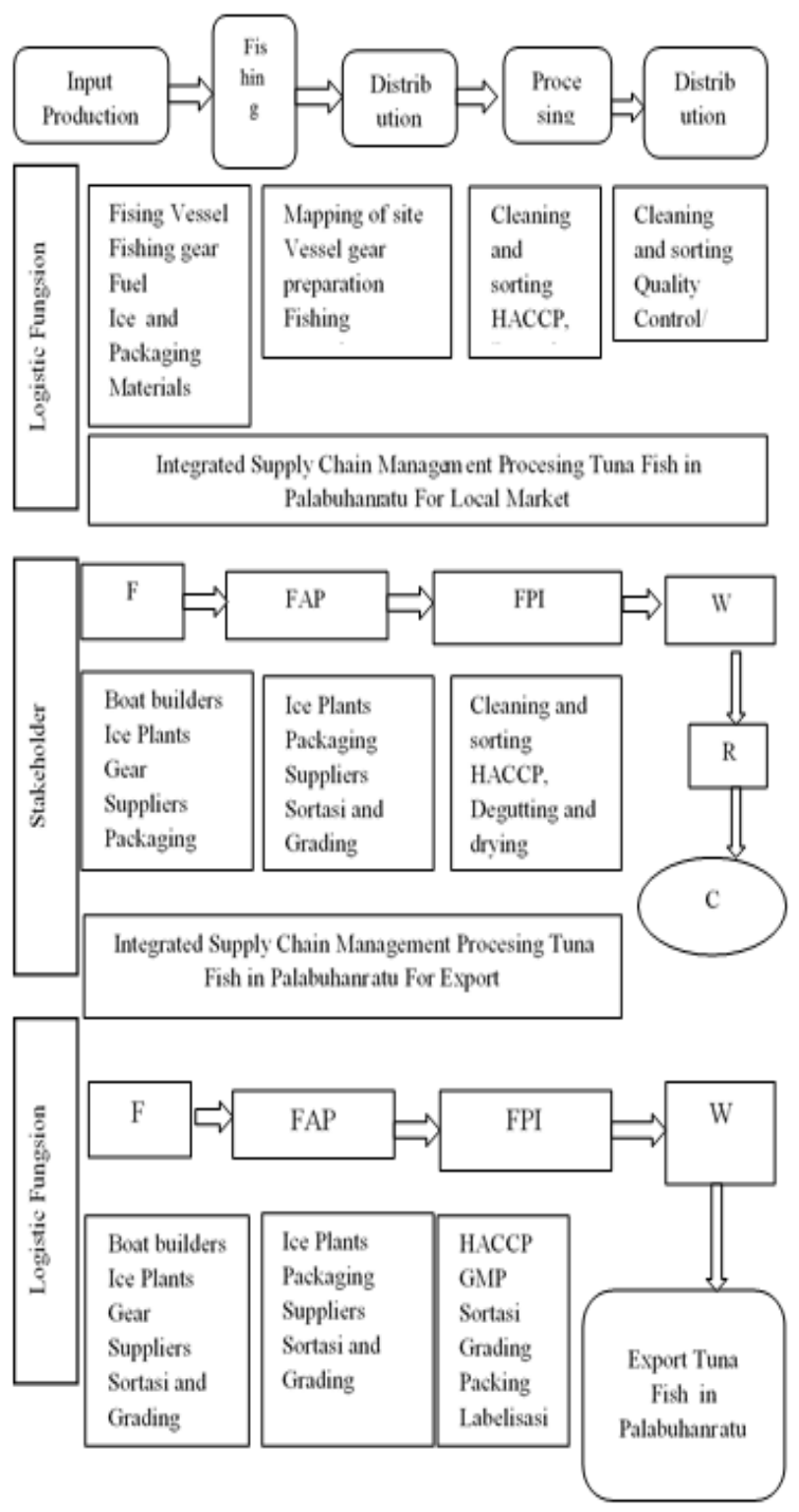

F : Fisherman

FAP: Fish Auction Place

W : wholesaler

FPI: Fish Processing Indexs

Fig 3, Framework Integrted Supply Chain Management Proccesing Tuna Fish In Palabuhanratu
Table 3. Consequence Risk Supply Chain For Tuna Fisheries In Palabuhanratu.

\begin{tabular}{|c|c|c|c|c|c|}
\hline No. & $\begin{array}{c}\text { Types of } \\
\text { supply } \\
\text { chain risks }\end{array}$ & $\begin{array}{c}\text { Scor } \\
\text { e }\end{array}$ & $\begin{array}{l}\text { Res } \\
\text { ults }\end{array}$ & $\begin{array}{c}\text { Conseque } \\
\text { nce }\end{array}$ & Information \\
\hline 1. & $\begin{array}{l}\text { Availability } \\
\text { of tuna } \\
\text { productions }\end{array}$ & $\frac{7}{7}$ & 1 & Important & Irreplaceable \\
\hline 2. & $\begin{array}{l}\text { Availability } \\
\text { of fishing } \\
\text { vessels and } \\
\text { fishing gear }\end{array}$ & $\frac{90}{180}$ & $\begin{array}{l}0.5 \approx \\
0.6\end{array}$ & Necessary & $\begin{array}{l}\text { Not easy to } \\
\text { replace }\end{array}$ \\
\hline 3. & $\begin{array}{l}\text { Availability } \\
\text { of fisheries } \\
\text { production } \\
\text { inputs }\end{array}$ & $\frac{2}{7}$ & $\begin{array}{l}0.3 \approx \\
0.6\end{array}$ & Necessary & $\begin{array}{l}\text { Not easy to } \\
\text { replace }\end{array}$ \\
\hline 4. & $\begin{array}{l}\text { Handling of } \\
\text { tuna } \\
\text { products after } \\
\text { catching and } \\
\text { processing }\end{array}$ & $\frac{1}{1}$ & 1 & Important & Irreplaceable \\
\hline 5. & $\begin{array}{l}\text { Sales system } \\
\text { with an } \\
\text { auction }\end{array}$ & $\frac{14}{14}$ & 1 & Important & Irreplaceable \\
\hline 6. & $\begin{array}{l}\text { Handling of } \\
\text { products } \\
\text { when } \\
\text { transporting } \\
\text { fishery } \\
\text { products } \\
\text { from each } \\
\text { distributor }\end{array}$ & $\frac{5}{14}$ & $\begin{array}{c}0.5 \approx \\
0.6\end{array}$ & Necessary & $\begin{array}{l}\text { Not easy to } \\
\text { replace }\end{array}$ \\
\hline 7. & $\begin{array}{l}\text { Natural } \\
\text { conditions of } \\
\text { population, } \\
\text { growth and } \\
\text { distribution } \\
\text { of tuna }\end{array}$ & $\frac{90}{90}$ & 1 & Important & Irreplaceable \\
\hline 8. & $\begin{array}{l}\text { Handling of } \\
\text { unsold } \\
\text { procesing } \\
\text { fish products } \\
\text { for fish feed } \\
\text { ingredients }\end{array}$ & $\frac{365}{1095}$ & 0.3 & Needs & Easily replaced \\
\hline 9 & $\begin{array}{l}\text { Avoiding the } \\
\text { risk of fraud } \\
\text { in the } \\
\text { marketing } \\
\text { supply chain }\end{array}$ & $\frac{9}{9}$ & 1.0 & Important & Irreplaceable \\
\hline
\end{tabular}

Tuna supply chain management in Plabuhanratu needs to be improved. In table 3 can be see consequence risk supply chain for tuna fisheries in Palabuhanratu: (1) availability of tuna productions,it is mean when the stock of tuna on the provider of raw materials are not available, for 7 consecutive days traders and processors of tuna will suffer a loss in the sense of doing the production, (2) availability of fishing vessels and fishing gear, during the high season catch season must be available within 180 days, based on research results in the field of fishing vessels and fishing gear on average available for 90 days in the high season of tuna fishing,(3) availability of fisheries production inputs including ice availability, packaging which means that the consequences of the risk are not easily replaced or necesarry because of the nature required (4) handling of tuna products after catching and processing is importance because perisabhle fisheries products, (5) sales system with 
an auction system to reduce the risk of payment systems between fishermen, baskets or intermediary traders and distributors, takes a maximum of 14 days for export payments, (6) handling of products when transporting fishery products from each distributor averange 5 days from each marketing channel, (7) the natural condition of the population, growth and distribution of tuna is very important for the continuity of production, (8) Handling of processed fish products that are not sold for fish feed ingredients needs to be done in order to continue to have economic value, (9) avoid the risk of fraud in the tuna marketing supply chain both in the domestic and export markets.

\section{Conclusion}

This research found that integrated supply chain for tuna fisheries is relevant. It should be made through integrative approach to incorporate tools necessary to mitigate negative influential factors and to take advantage the positive ones. The introduction of the integrated suppy chain should be done. Operationally, this includes a number of actions namely optimizing the connectivity, e.g mainly through development of better infrastructure, improving the people understanding about standarized quality of fisheries product and development distribution which follows a supply chain management framework.

\section{References:}

[1] Agency of Marine and Fisheries, Sukabumi West Java Province, 2014. Statistic Report on Capture Fisheries. Sukabumi.

[2] Hutapea, R. Y. F. 2017. Peran Pelabuhan Perikanan Samudera Nizam Zachman Jakarta dalam Mendukung Industri Perikanan Tuna. Tesis. Program Studi Teknologi Perikanan Laut. Institut Pertanian Bogor. Bogor. 94 hlm.

[3] Kementrian Kelautan dan Perikanan Palabuhanratu. 2018. Laporan Tahunan Statistik Perikanan Tangkap tahun 2007/2017 (The Annual Statistical Report Capture Fisheries In 2007/2017). Sukabumi.

[4] Food and Agricultural Organization. 2006. Agricultural Commodity Markets and Trade.

[5] Nurhayati, A., Purnomo, A.H. (2017)..Developing the Marine and Fisheries Industry in Pangandaran using a BioecoregionBased Technopark Framework. Journal of STI Policy and Management, 2(1), 43-52

[6] Pujawan, I Nyoman. 2010. Supply Chain Management. Penerbit Guna Widya, Surabaya.
[7] Indrajit RE dan R Djokopranoto. 2002. Konsep Manajemen Supply Chain Cara Baru Memandang Mata Rantai Penyediaan Barang. Jakarta (ID). Grasindo

[8] De Silva, D. 2011. Value chain of fish and fishery products: origin, functions and application in developed and developing country markets. FAO Value Chain Project Reports. Rome, FAO. 63 pp. (also available at www.fao.org/valuechaininsmallscalefisheries/ projectreports/en/).

[9] Nurhayati.,et.al Bioecoregion and SocioEconomic Connectivity Oriented Coastal Zone Management. Applied Ecology and Environmental Sciences, 2018, Vol. 6, No. 1, 31-34.

[10] Nurhayati.,et.al.2018.Promoting innovative business in the fishery sector in West Java, Indonesia. IOP Conf. Series: Earth and Environmental Science 137 (2018) 012100.

[11] Nurhayati.A.,et.al.2019. An Integrated Supply Chain Management Based Nila Nirwarna (Oreochromis niloticus) Seed Market Institution. Jurnal Perikanan Universitas Gajah Mda. Vol 21 No 2 Editon December 2019.

[12] Mariman \& Magfiroh 2010. Technical Application of Decision Making in Supply Chain Management. IPB Press 281 page

[13] Sugiyono. 2010. Educational Research Methods Quantitative, Qualitative and R\&D Approaches. Alfabeta

[14] Fisheries Port Information Center.2019. Palabuhanratu Fishery Port. http://pipp.djpt.kkp.go.id/profil_pelabuhan/117 4/informasi. Access 24 December 2019.

[15] Adyas, H. A., I. M. Zainudin, M. Yusuf. 2011. Panduan Pengoperasian Tuna Longline Ramah Lingkungan untuk Mengurangi Hasil Tangkapan Sampingan (Bycatch). Versi 1 Oktober 2011. WWF-Indnoesia

[16] Firdaus, M. dan C.M Witomo. 2014. Analisis Tingkat Kesejahteraan dan Ketimpangan Pendapatan Rumah Tangga Nelayan Pelagis Besar di Sendang Biru, Kabupaten Malang, Jawa Timur. Jurnal Sosial Ekonomi Kelautan dan PerIkanan Vol 9 No 2 (2014). Pusat Penelitian Sosial Ekonomi Kelautan dan PerIkanan. Jakarta

[17] Tjiptoherijanto P. 2001. Proyeksi Penduduk, Angkatan Kerja, Tenaga Kerja, dan Peran Serikat Pekerja dalam Peningkatan Kesejahteraan. Majalah Perencanaan Pembangunan Edisi 23.

[18] Nakamura H. 1969. Tuna Distribution and Migration. Fishing News (Books) LtdLondon. 
[19] Regulation of The Minister of Marine and Fishereiesof The Republic of Indonesia Number 5/Permen-KP/ 2014 Concering National Fish Logistic System.

[20] Nurhayati A, Purnomo AH. 2018. TechnoSosio-Economic Analysis of Losses in Capture Fishery: A Case Study in Pelabuhan Ratu, Sukabumi, West Java Province. Earth and Environmental Science 139 (2018) 012034

[21] Carpenter, K.E. \& V.H. Niem. 2001. The living marine resources of the Western Central Pacific. FAO Identification Guide for Fishery Purposes. Vol. 6.

[22] Zulbainarni, Nimmi. 2016. Revised Edition of Theory and Practice of Bioeconomic Modeling in Capture Fisheries Management. Bogor: IPB Press

[23] Wujdi, A. \& Suwarso. 2014. Fluctuation and Catch Composition of Neritic Tuna Species Caught by Gillnet In The South China Sea Waters. Jurnal Penelitian Perikanan Indonesia. Research Center for Fisheries Management and Fish Resource Conservation, Vol. 20, No.(1):207-214.

[24] Neves Dos Santos, M. \& A. Garcia, 2006. Observations on the catches of small tunas from a tuna trap off the Algarve (southern Portugal). ICCAT, Coll. Vol. Sci. Pap., 59 (3): 802-812.

[25] Herera, M., \& Pierre, L. (2009). Status of IOTC databases for neritic tuna. IOTC-2009WPDCS-06, 46.

[26] Maguire, J.J., Sissenwine, M., Csirke, J., Grainger, R., \& Garcia, S. (2006). The state of world highly migratory, straddling and other high seas fishery resources and associated species. FAO Fisheries Technical Paper, 495. Rome: FAO.

[27] Nurhayati.,A.2013.Sustainable Potential Analysis of Capture Fisheries in Pangandaran Area. Journal Akuatika Vol IV/No 2/September 2013.(195-209).

[28] Nurhayati.,A.2018. Fisheries Sociology Approach Aquatic Preneurship. Unpad Press, Pages 117.

[29] Regulation of the minister of marine and fisheries of the Republic of Indonesia, No 5/Permen-KP/2014. About the national fish logistic system. 